\title{
Legal Regulations to Tax Administration in Vietnam: Changes and Improvements
}

\begin{abstract}
Thi Kieu Oanh $\mathrm{Vu}$ *
Peoples' Friendship University of Russia, Moscow, Russia Federation

*Corresponding author. Email: kieuoanh2205hlu@gmail.com

ABSTRACT

Taxation and tax administration are an essential part of ensuring a country's stability and regular operation. The requirements for openness, transparency, modernity, reasonableness, and legitimacy poses challenges to the legislative, executive, and judiciary branches regarding taxation. This article analyzes the legal changes to taxation as a component of the administrative law associated with Vietnam's legal context. The methods used aimed to clarify the research problem, including analysis, synthesis, and comparison. The article's main research source is the Law on Tax Administration 2006 (called Law 2006) and the Law on Tax Administration 2019 (called Law 2019). This study confirms that progress has been seen in changes in tax administration regulations in Vietnam. Simultaneously, the law needs to consider two critical issues - the organization of tax administration agencies and tax disputes — when building a relationship between tax administration agencies and taxpayers.
\end{abstract}

Keywords: Tax administration, Tax dispute, Vietnam, Regulation, Legal.

\section{INTRODUCTION}

Vietnam's tax law has a history of being developed in association with the Vietnamese economy's movement, with essential taxation reforms from 1990 to the present. Before 1990, centralized tax administration irrationalities were common in both the building of tax legislation and in the operations of tax collectors. This occurred because the legal regulations at that time had not been built on accurate views of taxation as an important resource or economic leverage. This led to a lack of comprehensive policies and of a discrete tax legal system. The bureaucracy of tax administration was fragmented and did not yet operate under a single entity. The unfortunate results included discrimination in tax collection for enterprises and the omission of revenue sources. These troubles returned, causing difficulties for tax collection by state agencies. The landmark significance of the change in Vietnam's tax legislation in 1990 is reflected in the legal documents on taxation, including:

- Sales tax;

- Special consumer tax;

- Income tax;

- High-income tax;

- Import and export taxes;

- Natural resources tax;
- Real estate tax (applied as land tax, not as housing $\operatorname{tax}$ );

- Agricultural land use tax;

- A regime of revenue and use of state budget capital;

-Principles of petitioners' right to decide and self-determination.

Over time, the sales tax was replaced by a Value Added Tax, and the income taxes were replaced with a corporate income tax. The enactment of Law 2006 [1] marked the second major milestone in tax law reform and is closely related to the event of Vietnam joining the World Trade Organization. On July 1, 2020, Law 2019 [2] officially came into effect, indicating significant progress in the tax field's legal adjustment. However, challenges are still encountered in the implementation of this law. Typically, the impact of international economic integration on the national tax system changes the tax structure, increases tax competition, and causes difficulties in international tax administration [3]. 


\section{RESULTS AND DISCUSSION}

\subsection{Significant Changes in Tax Legislation}

\subsubsection{Ensuring the Rights and legitimate Interests of Taxpayers.}

Taxpayers are entitled to 14 rights, as set forth in Article 16 of Law 2019. These are in addition to the fundamental rights from Law 2006, such as the rights to be supported, guided, educated, and have one's information kept confidential; to enjoy incentives; to be compensated for damage; and to complain and denounce. Law 2019 has added many new rights, including: to receive documents related to tax liabilities from competent authorities upon inspection, review, and/or audit; to enjoy tax incentives and/or tax refunds in accordance with tax regulations; to be informed of tax refund schedules, non-refundable taxes, and the legal bases of non-refundable taxes; to have printed access to all electronic records that taxpayers have sent to web portals of tax authorities, as prescribed in this law and in the law on e-transactions; and to use electronic records in transactions with tax authorities and relevant organizations and/or individuals. Broadly speaking, this content also contributes to harmonizing the relationship between the state and the taxpayer. Legal adjustment in the tax field is part of a process of tax policy reform in Vietnam toward progress and greater consistency with the general development trends of contemporary tax policies. Law 2019 and Law 2006 gave more proactive power to taxpayers. This means that taxpayers have the right to complain and initiate a tax lawsuit against the tax authorities, as well as that the State is obliged to compensate taxpayers when they suffer losses due to illegal tax collection.

\subsubsection{Rationalization of Legal Regulations.}

Two highlights of Law 2019 include extending the deadline for filing finalized personal income tax and adding tax payment extension. Specifically, Law 2019 extends the deadline set in Law 2006 for submitting personal income tax finalization dossiers by one month (Article 44 of Law 2019). Additionally, material damage directly affecting production and business due to a force majeure, such as a disaster or epidemic, is a typical case of eligibility for tax deferral according to Law 2019. The effects of this provision have been brought into full play during the COVID-19 pandemic that is currently ongoing [4]. Broadly, the rationalization for these tax regulations is related to the existence and continuous improvement of tax incentives. Tax incentives are a common practice of economies around the world; for Vietnam, this policy is meant to create an attractive investment environment and stimulate the economy. In Vietnam, tax incentives are found in a number of categories, such as tax rates, tax exemption period, and tax reduction (including corporate income, personal income tax, and import-export tax).

\subsubsection{Modernization of Legal Regulations.}

Specifically, Law 2019 mandates the use of e-invoices starting on July 01, 2022, while encouraging agencies, organizations, and individuals to apply regulations to electronic invoices and documents before July 01, 2022. This is considered appropriate in the context of the increasingly widespread e-commerce in Vietnam.

\subsubsection{Transparency of Legal Regulations.}

The principles of tax declaration and tax calculation for e-commerce business activities and associated transactions promote strict management of tax evasion; these are regulated by Law 2019 in the following ways:

(1) For electronic commerce, even if an overseas supplier does not have a permanent establishment in Vietnam, it is still obliged to directly engage in or authorize tax registration, tax declaration, and tax payment in Vietnam (Article 42 of Law 2019);

(2) For associated transactions, the principle of analysis and comparison with independent transactions, along with the nature of operation and the nature of the transaction, must be ensured in order to determine tax liability in the same manner as for transactions between independent parties (Article 42 of Law 2019).

\subsubsection{Refering Directly to the "Gaps" in Tax Administration.}

The prohibited acts according to Law 2006 include: causing trouble for or harassing taxpayers; taking advantage of or illegally using tax money; using tax identification numbers of other taxpayers to commit violate the law, or allowing others to use their tax identification numbers to violate the law; and falsifying, misusing, illegally accessing, or destroying taxpayer information systems. Law 2019 adds several prohibited acts in tax administration, specifically: collusion, connection, or cover-up between taxpayers, tax officials, and/or tax authorities for price changes and/or tax evasion; deliberate avoidance of declaration or inadequate, late, or inaccurate declaration of tax liabilities; obstruction of the operations of tax officials; sale of goods and provision of services without issuance of invoices as prescribed by law, or use of illegal invoices and/or illegal use of invoices; and alteration, misuse, illegal access, or destruction of taxpayer information systems. These are critical legal bases that limit the behavior of entities involved in tax administration and that contribute to dealing with complicated violations in the tax field, such as transfer pricing and tax evasion. The wrongdoings should be situated within the cultural factors in order to establish more preventive and proactive regulations from a broader perspective, because the national culture affects the perception of tax evasion. 
This has been pointed out by Natalia Ermasova [5] in research on the relationship between culture and tax evasion in the US and Germany.

In short, the changes that were made reflect very progressive trends in Vietnamese tax legislation. Bird [6] has examined tax administration in developing countries and claims that no universal formula exists; instead, he suggested eight general approaches to improve this problem, including: know the context, keep it simple, have a reform strategy, the taxpayer as client, compliance costs matter, manage information technology properly, keep your eye on the ball, and deal with non-compliance. These suggestions, established in the above-mentioned changes in Vietnam's law, are particularly relevant.

\subsection{Organizational Problems of Tax Administration Agencies}

Tax administration agencies in Vietnam include two branches: (1) the General Department of Taxation, with provinces' Departments of Taxation and districts' Sub-departments of Taxation; (2) the General Department of Vietnam Customs, with the Departments of Customs, the Post Clearance Audit Departments, and the Sub-department of Customs. In general, an organization of the tax administration apparatus from central to local levels has led to a centralized and coherent system. The content of these agencies' responsibilities and powers around the core contents of tax administration has been institutionalized, as specified in Article 4 of Law 2019. However, the operation of these agencies is an issue that needs attention. This issue also exists in more developed countries, such as the Russian Federation. According to research by Tsvetkov et al. [7], despite the positive impact of tax reforms, the organizational problem is a significant aspect that can help or hinder significant optimization of tax administration in a country. As a result, scholars have discussed the organizational problems of tax administration. In terms of Vietnam, three organizational issues need to be addressed.

The first organization issue involves publicity and transparency of the tax administration's operations and transparency of assets and income of officials and public employees. These can be dealt with through internal inspection of sensitive and potentially negative areas. In this way, it is possible to detect and deal with people creating difficulties for taxpayers or violating discipline and law.

The second issue is streamlining the tax administration apparatus. According to the Government Office of the Socialist Republic of Vietnam [4], the Taxation branch has eliminated 2,189 intermediaries, merging with 565 Tax Departments to establish 269 regional Tax Departments. When the number of Tax Departments fell from 711 to 415 , the number of tax-serving officers decreased by more than 850 . These figures indicate the unnecessary bulkiness of the tax collector system. Therefore, reduction needs to continue set in order to bring optimal efficiency for the country's taxation administration. However, the apparatus's streamlining should also be accompanied by improving the quality of human resources in tax administration. According to Tran [3], high-quality human resources is a challenge in tax collection efforts for cross-border commercial transactions (services and goods in particular) and business activities in the digital economy.

The third issue is reform of the administrative procedures of tax authorities. This issue's multifaceted benefits are shown by the reductions in time and costs as well as in the maximum convenience for businesses and taxpayers. Therefore, projects applying information technology in tax collections and payments should continue to be deployed. Such projects are related to the increase in organizations and businesses that use electronic tax registration, electronic tax declarations, electronic tax payments, electronic payments ratio to the value of total tax revenues, and electronic tax refund in Vietnam. Furthermore, the direction of administrative procedure reform should take its cue from current international practices. Administrative reform must go hand-in-hand with effective risk management in tax registration, tax declaration, tax payment, and tax refund.

\subsection{Tax Disputes}

Taxes are essentially social and economic means to goals based on the idea of a just and democratic society. However, according to Nguyen [8], the state and the taxpayer's relationship is sensitive. For a long time, classical theories of taxation have absolutized the "power" of the state. In contrast, in Nguyen's [8] analysis, modern economic theories acknowledge the connection with taxation's political problems, but they explain that the State cannot arbitrarily formulate tax policies, because-in principle-tax policies are approved by the representatives of the people. In practice, tax disputes still occur due to self-regulation of tax administration regulations.

\subsubsection{Tax Disputes in Vietnam.}

The most common tax disputes in Vietnam are procedural disputes and disputes over revenues. Tax procedures in Vietnam today include: tax registration, tax declaration, tax payment, tax assessment, and tax identification number; procedures for buying and printing invoices and vouchers; tax settlement procedures; tax refund, tax exemption, and tax reduction procedures; procedures for tax and fine-related debt write-offs; tax examination and tax inspection procedures; procedures for coercive execution of tax administrative decisions; procedures for handling tax law 
violations; and procedures for settling tax complaints and denunciations, among others. A dispute over tax revenue arises when there is a conflict or disagreement between a taxpayer and a tax authority or between a taxpayer and a competent tax officer over the payable tax amount. This dispute may have to do with the tax amount for which the tax is assigned or the tax amount's determination. Disputes over tax revenues are divided into disputes of individuals vs. tax administration agencies and disputes of organizations vs. tax administration agencies.

\subsubsection{Reasons and Solutions for Some Tax Disputes.}

With a dense set of regulations related to the procedures of tax return, tax collection, and tax assessment, procedural errors are the most likely errors to occur. In general, tax disputes arise when tax authorities' officials and employees create unfavorable conditions and difficulties for taxpayers, which prolong the implementation of tax procedures. Errors and issues related to the tax sector are also closely related to tax revenues, which are often incorrectly assigned. Many disputes involve the implementation of the law and the duration of concessions, taxpayers, and tax calculation methods. In many disputes, the value of the dispute is very great - sometimes up to tens or hundreds of billions of Vietnamese Dong [9].

One resolution method may be to settle tax complaints and resolve tax administrative cases. According to a study by Nguyen [9], it is necessary to have separate guidance concerning the time limit for settling tax complaints. It can be argued that tax disputes resolved according to administrative procedures are different from other administrative disputes. The settlement of complaints by simple complaint procedures is challenging in terms of ensuring objectivity, especially in the context of the final complaint settlement agency being the agency issuing documents and guiding the law's application. Therefore, when the law is not specific and clear, it is difficult for taxpayers to have their interests protected under the law [3].

To ensure adequate tax dispute settlement, certain principles should be respected. Principles for settling tax complaints should include: respecting citizens' right to complain; complaints and complaint settlements must comply with the provisions of the law; implementing legally-effective decisions on tax complaint settlements. Wrong tax decisions are not only resolved through the settlement of complaints and denunciations, but also through the Court. In such cases, the principles of handling administrative cases in the tax domain include the general principles of justice and the specific principles of administrative proceedings in the tax domain. These principles derive from the principles of tax-related administrative disputes and tax-related administrative proceedings, including:
-The principle of the rights of individuals and organizations to request the Court to protect their legitimate rights and interests (i.e., the principle of ensuring the right to initiate a tax-related administrative lawsuit);

-The principle of the settlement of damage compensation in tax-related administrative cases;

- The principle of the petitioner's right to decide and self-determine.

\section{CONCLUSION}

Tax administration law is an issue of great significance in many aspects of state operation and of international economic integration. The improvement of legal adjustments to this issue has contributed to ensuring taxpayers' rights and interests within the framework of Vietnam's tax policy reform. The trends of rationalization, modernization, and transparency of legal regulations - clearly pointing to the "gaps" in tax administration - have been demonstrated in Vietnam. The two concerns of establishing a proper tax administration system and resolving tax disputes according to correct principles persist in tax administration. The State's tax administration efforts are remarkable, but they still need to continue in the future.

\section{REFERENCES}

[1] The National Assembly of the Socialist Republic of Vietnam, Law on tax administration No. 78, November 29, (2006), retrieved from https://thuvienphapluat.vn/van-ban/thue-phi-le-phi/ Luat-quan-ly-thue-2006-78-2006-QH11-15871.asp $\mathrm{x}$

[2] The National Assembly of the Socialist Republic of Vietnam, Law on tax administration No. 38, June 13, (2019), Retrieved from https://www.tracuuphapluat.info/2011/10/luat-quan -ly-thue-tieng-anh-law-on-tax-administration.html

[3] T. V. A. Tran, Some issues of tax administration in the context of international economic integra-tion, Journal of Finance 1 (3) (2020) 35-40. Retrieved fromhttp://tapchitaichinh.vn/nghien-cuu-trao-doi/m ot-so-van-de-ve-quan-ly-thue-trong-boi-canh-hoi-n hap-kinh-te-quoc-te-322313.html

[4] The Government Office of the Socialist Republic of Vietnam, Continue to promote tax administrative procedure reform, (2020), Retrieved from http://vpcp.chinhphu.vn/Home/Tiep-tuc-day-manhcai-cach-thu-tuc-hanh-chinh-thue/20203/27364.vgp

[5] N. Ermasova, C. Haumann \& L. Burke, The Relationship between Culture and Tax Evasion across Countries: Cases of the USA and Germany, International Journal of Public Administration 10 

(2019)
$1-17$.
DOI:
10.1080/01900692.2019.1672181.
(6) (2017) 34-49. DOI 10.26794/2587-5671-2017- 21-6-34-49

[6] R. M. Bird, Improving Tax Administration in Developing Countries, Journal of Tax Administration 1 (2015) 23-45.

[7] V. A. Tsvetkov, A. A. Shut'kov, M. N. Dudin \& N. V. Liasnikov, Improvement of the tax administration in system in Russia, Scientific and Practical Journal 21
[8] V. T. Nguyen, The nature of taxation - approaches from classical and modern tax doctrines, Journal of Law 4 (2009) 15-24.

[9] T. L. H. Nguyen, The Features in Resolving Tax Disputes under the Administrative Procedure, Journal of Law 31 (1) (2015) 11-22. 